\title{
Seasonal variations in composition, properties, and heat-induced changes in bovine milk in a seasonal calving system
}

\author{
Siqi Li, Aiqian Ye, ${ }^{*}$ and Harjinder Singh \\ Riddet Institute, Massey University, Private Bag 11 222, Palmerston North 4442, New Zealand
}

\section{ABSTRACT}

We determined seasonal variations in the composition and characteristics of bovine milk, as well as heat-induced changes in the physicochemical properties of the milk, in a typical seasonal-calving New Zealand herd over 2 full milking seasons. Fat, protein, and lactose contents varied consistently during the year in patterns similar to those of the lactation cycle. Seasonality also had significant effects on milk calcium, ionic calcium, fat globule size, buffering capacity, and ethanol stability, but not on casein micelle size. The ratio of casein to total protein did not vary significantly over the season, but late-season milk had the highest content of glycosylated $\kappa$-casein $(\mathrm{G}-\kappa-\mathrm{CN})$ and the lowest content of $\alpha$-lactalbumin in both years. We observed significant between-year effects on protein, total calcium, ionic calcium, $\mathrm{pH}$, and casein:total protein ratio, which might have resulted from different somatic cell counts in the 2 years. Compared with heating at $90^{\circ} \mathrm{C}$ for $6 \mathrm{~min}$, UHT treatment $\left(140^{\circ} \mathrm{C}\right.$ for $\left.5 \mathrm{~s}\right)$ induced greater dissociation of $\kappa$-casein, a similar extent of whey protein denaturation, a lower extent of whey protein-casein micelle association, and a larger increase in casein micelle size. Indeed, UHT treatment might have triggered significant dissociation of G-k-CN, resulting in aggregation among the casein micelles and increased apparent mean casein micelle diameter. Seasonality had significant effects on the partitioning of G- $\kappa-\mathrm{CN}$ between the micelle and the serum phase, the extent of whey protein-casein micelle association under both heating conditions, and the casein micelle size of the UHT milk.

Key words: milk composition, seasonal variation, physicochemical property, heat treatment, $\kappa$-casein glycosylation

Received March 25, 2019.

Accepted May 23, 2019.

*Corresponding author: A.M.Ye@massey.ac.nz
INTRODUCTION

The composition and physicochemical properties of milk are of great importance for the dairy industry. They have marked effects on the processing properties of the milk and the quality of dairy products (O'Brien and Guinee, 2011). The characteristics of milk are affected by various factors, including breed, season, stage of lactation (SOL), feeding, parity, and the health status of the cow (Fox and McSweeney, 1998).

Patterns in the seasonal variation of the composition and properties of milk vary considerably in different countries because of differences in calving systems, feeding strategies, and climate (Grimley et al., 2009; Heck et al., 2009). In seasonal-calving countries (e.g., New Zealand, Australia, and Ireland), most cows calve in late winter to spring to maximize the use of pasture as the major feed source. This synchronized calving practice results in a pattern of seasonal variation in milk composition that is controlled by SOL (Lucey, 1996; Auldist et al., 1998). In most European countries, calving is not seasonal and a change in diet is regarded as the main reason for seasonal variation in milk properties. The cows consume mainly silage and concentrates in winter and fresh grass in spring and summer (Lindmark-Månsson et al., 2003; Grimley et al., 2009; Heck et al., 2009). In countries with a warmer climate, the negative effect of heat stress in summer on milk composition has been emphasized (Bernabucci et al., 2002; Bertocchi et al., 2014).

Previous studies in seasonal calving countries have reported that milk protein and fat content increased toward the end of the milking season, and lactose content decreased (Phelan et al., 1982; Auldist et al., 1995, 1998). Such seasonal trends are consistent with patterns of variation in milk composition during the lactation cycle (Ng-Kwai-Hang et al., 1982; Walstra and Jenness, 1984; Barłowska et al., 2014). However, there were contradictions among studies in the seasonal and lactational variation patterns of some milk characteristics (e.g., protein composition and $\mathrm{pH}$ ). Differences in herd management, climate, and herd health status might account for these inconsistent seasonal trends 
(Chen et al., 2014). In particular, SCC, as an important indicator of udder health and milk quality, differed considerably among studies (Ng-Kwai-Hang et al., 1982; Ostersen et al., 1997; O'Connell et al., 2017). Therefore, the effect of high SCC on milk characteristics might confound variations during different seasons or SOL. In addition, because most seasonal studies were conducted for 1 year, they could not account for between-year differences (e.g., variations in climatic conditions) that may affect milk quality.

Heat treatment is a common practice during milk processing to improve the keeping quality of the milk by deactivating microorganisms and enzymes. It can also enhance the textural quality of some dairy products, such as yogurt (Vasbinder and De Kruif, 2003). With heating at temperatures above $70^{\circ} \mathrm{C}$, there is irreversible denaturation of whey proteins and their association with casein micelles (Wijayanti et al., 2014). Anema and Li (2003) demonstrated that the whey protein-casein micelle association resulted in an increase in casein micelle size. Heating of milk also induces the dissociation of $\kappa-\mathrm{CN}$ from the casein micelle surface, influencing whey protein-casein micelle interactions and the heat stability of the milk (Singh and Fox, 1985; Anema and Klostermeyer, 1997; Donato et al., 2007). This heat-induced protein association and dissociation have been reported to affect the acid gelation properties of milk, the age gelation of UHT milk, and the solubility of protein isolates (Grufferty and Mulvihill, 1987; McMahon, 1996; Donato and Guyomarc'h, 2009). To our knowledge, the effect of seasonality on heatinduced changes in milk has rarely been reported.

The aim of the present study was to investigate seasonal variations in the composition and characteristics of milk in a seasonal-calving New Zealand herd, as well as heat-induced changes in the physicochemical properties of the milk during season under 2 typical heat treatments used in dairy processing. Analysis was carried out for 2 full milking seasons to identify which quality parameters varied consistently by season, regardless of between-year effects.

\section{MATERIALS AND METHODS}

\section{Milk Supply and Heat Treatment}

Milk was taken from Massey University No. 4 dairy farm (Palmerston North, New Zealand) for 2 full milking seasons, from August 2016 to May 2018. The herd consisted of 614 cows, mostly Friesian-Jersey crossbreed. In both seasons, the herd started calving in late July and dried off in May. In total, 39 samples were collected in the 2 milking seasons, 2016-2017 and 2017-2018. Early season, mid-season, and late season were defined as 8 to 100,101 to 220 , and 221 to 300 DIM, corresponding to August-October, NovemberFebruary, and March-May in each year.

Fresh whole milk was pasteurized at $72^{\circ} \mathrm{C}$ for $15 \mathrm{~s}$ and skimmed using a centrifugal separator (model $103 \mathrm{AE}$, Alfa-Laval, Lund, Sweden) at $50^{\circ} \mathrm{C}$. The skim milk was then heated at $90^{\circ} \mathrm{C}$ for 6 min or at the UHT (indirect) condition of $140^{\circ} \mathrm{C}$ for $5 \mathrm{~s}$. Samples were preserved with $0.02 \%$ (wt/wt) sodium azide. Aliquots of samples were frozen at $-20^{\circ} \mathrm{C}$ before compositional analysis.

\section{Characterization of Milk Physicochemical Properties}

Milk protein, fat, and lactose content were measured using a MilkoScan FT120 (Foss Electric, Hillerød, Denmark). The farm provided SCC data on collection days. Milk total calcium and inorganic phosphorus content were analyzed on an RX Daytona Plus analyzer using reagents CA 8309 and PH 8328 (Randox Laboratories, Crumlin, UK).

Milk $\mathrm{pH}$ was measured using a CyberScan $\mathrm{pH} 510$ $\mathrm{pH} / \mathrm{mV}$ meter (Eutech Instruments-Thermo Scientific, Singapore). A calcium-selective electrode (Orion 9720BNWP; Thermo Scientific) was used to determine the ionic calcium $\left(\mathrm{Ca}^{2+}\right)$ concentration. Calibration was carried out with 5 standards containing 1.0, 2.0, 3.0, 4.0 , and $5.0 \mathrm{mM} \mathrm{CaCl}_{2}$. The ionic strengths of the standards were adjusted to $80 \mathrm{~m} M$ with potassium chloride, as described by Geerts et al. (1983). All milk samples and calibration solutions were allowed to equilibrate for at least $60 \mathrm{~min}$ in the same water bath at room temperature before analysis. This practice allowed all calibrations and measurements to be performed at the same temperature $\left(20 \pm 2^{\circ} \mathrm{C}\right)$.

Milk fat globule size was determined using a Malvern MasterSizer 2000 (Malvern Instruments Ltd., Malvern, UK). Sample preparation and measurement were carried out according to Ye et al. (2002). Milk samples were mixed 1:1 with a solution containing $2 \%$ SDS and $50 \mathrm{~m} M$ EDTA, pH 6.7, to dissociate the casein micelles. Measurement of each sample was at least in triplicate.

The hydrodynamic size of the casein micelles was analyzed on a Zetasizer Nano ZS (Malvern Instruments Ltd.), using a method modified from Bijl et al. (2014). Skim milk samples were diluted 50 times in their own ultrafiltration permeate and filtered with $0.45-\mu \mathrm{m}$ polyvinylidene fluoride syringe filters. Samples were measured at $20^{\circ} \mathrm{C}$ using a scattering angle of $173^{\circ}$. Measurement of each sample was at least in triplicate.

The buffering capacity of pasteurized skim milk was measured in duplicate according to Park (1991). The buffering capacity $(\mathrm{dB} / \mathrm{dpH})$ after the addition of $4 \mathrm{~mL}$ of $0.5 \mathrm{M} \mathrm{HCl}$ was calculated using the equation given by Van Slyke (1922): 
$\frac{\mathrm{dB}}{\mathrm{dpH}}=$

Volume of acid or base added $\times$ normality of acid or base

Volume of sample $\times \mathrm{pH}$ change produced

The ethanol stability of the pasteurized skim milk was determined as described by Huppertz et al. (2004). The buffering capacity and the ethanol stability were analyzed only in 2017-2018.

\section{Heat-Induced Whey Protein Denaturation Determined by Native PAGE}

Native whey proteins were separated from the casein micelles and denatured whey proteins using acetic acid precipitation as described by Vasbinder and De Kruif (2003). The supernatant containing the native whey proteins was collected for analysis by native-PAGE using a Mini-Protean electrophoresis system (Bio-Rad, Hercules, CA) as described by Singh and Creamer (1991). The staining intensities of the protein bands, as an indication of the relative protein concentrations, were quantified on a Gel-Doc XR+ system (Bio-Rad). The extent of whey protein (WP) denaturation was calculated as

$$
\begin{aligned}
& \text { WP denaturation }(\%)= \\
& \left(1-\frac{\mathrm{WP} \text { staining intensity in serum of heated milk }}{\mathrm{WP} \text { staining intensity in serum of raw milk }}\right) \times 100 \% \text {. }
\end{aligned}
$$

\section{Analysis of Protein Composition and $\mathrm{K}-\mathrm{CN}$ Glycosylation by HPLC}

Milk and milk serum samples were analyzed by reversed-phase HPLC to determine the protein composition of the milk, the glycosylation of $\kappa-\mathrm{CN}$, and the extent of the association between the whey proteins and the casein micelles in heated milk. Milk serum was obtained from raw milk and heated milk by ultracentrifugation at $88,000 \times g$ for $60 \mathrm{~min}$ at $20^{\circ} \mathrm{C}$.

Chromatographic conditions, protein identification, and protein quantification were performed as described by Bobe et al. (1998) on a reversed-phase C18 column (Aeris Widepore $3.6 \mu \mathrm{m}$ XB-C18 RP; Phenomenex, Torrance, CA). The glycosylated $\kappa-\mathrm{CN}(\mathbf{G}-\kappa-\mathbf{C N})$ and nonglycosylated $\kappa-\mathrm{CN}(\mathbf{N G}-\boldsymbol{\kappa}-\mathbf{C N})$ peaks were identified. The glycosylation degree (GD) of $\kappa-\mathrm{CN}$ was defined as the peak area ratio of G-k-CN in total $\kappa-\mathrm{CN}$. The extent of whey protein-casein micelle association was calculated as the difference in whey protein concentration between raw and heated milk serum samples.
The proportion of whey proteins forming aggregates in the serum phase was calculated as the difference between the total amount of whey protein denaturation and whey protein that is associated with casein micelle. Each sample was prepared and analyzed at least in duplicate.

\section{Statistical Analysis}

Statistical analysis was performed using SPSS version 24 (SPSS Inc., Chicago IL). The effects of seasonal variation, between-year variation, and different heat treatments, and their interactions on milk quality parameters, were analyzed by ANOVA with the Tukey post hoc test. The coefficient of variation and correlations among the parameters were also analyzed. For each parameter, statistical analyses were performed with 3 to 8 results per season per year.

\section{RESULTS AND DISCUSSION}

\section{Milk Composition}

Major Components. Table 1 shows the composition of the major milk components and minerals. Milk fat and protein content decreased from calving to their lowest levels around September-October in the early season and then gradually increased. In the late season, particularly April-May, fat and protein content increased markedly to their highest levels. Seasonal trends for fat and protein were consistent over the 2 years. Milk from 2017-2018 contained more protein than milk from $2016-2017(P<0.05)$. The concentration and dilution effect contributes to seasonal variation in fat and protein content as milk volume reaches a maximum in mid-lactation and decreases toward late lactation (Auldist et al., 1998). Lactose content was stable until mid-season and then dropped significantly during the late season. Lactose synthesis is suppressed in late lactation to adjust for increased osmotic pressure caused by the influx of blood constituents, because of the degeneration of the mammary epithelia toward the end of lactation (Fox, 2009).

The seasonal trends for milk fat, protein, and lactose were in agreement with reports from countries with seasonal calving (Phelan et al., 1982; Auldist et al., 1995; O'Connell et al., 2017), as well as with variation patterns during the lactation cycle (Ng-Kwai-Hang et al., 1982; Fox and McSweeney, 1998; Barłowska et al., 2014). The results of the current study add to the evidence that SOL controls seasonal variations in the composition of major milk components in a seasonal calving system. 
Somatic Cell Count. The SCC of all milk samples were $<200,000$ cells $/ \mathrm{mL}$, with annual averages of 86,158 and 152,053 cells/mL in 2016-2017 and 2017-2018, respectively. The SCC were low compared with European Union requirements of 400,000 cells $/ \mathrm{mL}$ and the target annual average SCC of 150,000 cells/mL recommended by DairyNZ (Hamilton, New Zealand). The low overall SCC in this study was an indication of good udder health and milk quality, minimizing the influence of excessively high SCC or mastitic milk on seasonal variations in milk properties.

Late-season milk had the highest SCC in both years, consistent with the well-documented trend that SCC increases in late lactation (Ng-Kwai-Hang et al., 1984; Auldist et al., 1996a; Lucey, 1996). Auldist et al. (1995) have suggested that a joint effect of decreasing milk volume and degeneration of the mammary gland resulted in the increase in SCC during late lactation.

Milk from 2017-2018 had a higher SCC than that from 2016-2017. The higher average temperature in 2017-2018 might have contributed to the higher SCC. Heat stress has been consistently reported to increase SCC in milk (Igono et al., 1988; Bernabucci et al., 2002; Bertocchi et al., 2014). The number of days with a daily maximum temperature of $24^{\circ} \mathrm{C}$ or higher (equivalent to a maximum temperature-humidity index of 74 or higher at $75 \%$ mean daily relative humidity) were $35 \mathrm{~d}$ in 2016-2017 and $80 \mathrm{~d}$ in 2017-2018 (Palmy Weather, 2019). The daily maximum temperature-humidity index of 74 was a threshold reported by Bertocchi et al. (2014), above which milk SCC would increase significantly.

Milk Minerals. The calcium content of the milk was highest in the late season in both years, consistent with reports that calcium content was higher in late lactation than in mid-lactation (O'Keeffe et al., 1982; Auldist et al., 1995, 1996a). Auldist et al. (1995) reported that milk calcium content varied during the year in a similar pattern to milk casein content, because a large proportion of the calcium in milk is present in the casein micelles, in the form of colloidal calcium phosphate. This may explain why milk from 2017-2018 had higher total calcium and protein content than milk from 2016-2017. The inorganic phosphorus content of the milk was lower in the early season in 2016-2017 but did not vary significantly in 2017-2018.

The mean $\mathrm{Ca}^{2+}$ concentration was lowest in midseason in both years, although in 2017-2018 the $\mathrm{Ca}^{2+}$ concentration was not significantly higher in the early season than in mid-season. The $\mathrm{Ca}^{2+}$ concentration had a strong correlation with total calcium content ( $\mathrm{r}$ $=0.642, P<0.01$ ) and a stronger one with calcium: inorganic phosphorus ratio $(\mathrm{r}=0.867, P<0.01)$. This may have been because the salt balance between cal-

Table 1. Compositional properties of seasonal milk $(n=5-8 \text { for each parameter per season per year })^{1}$

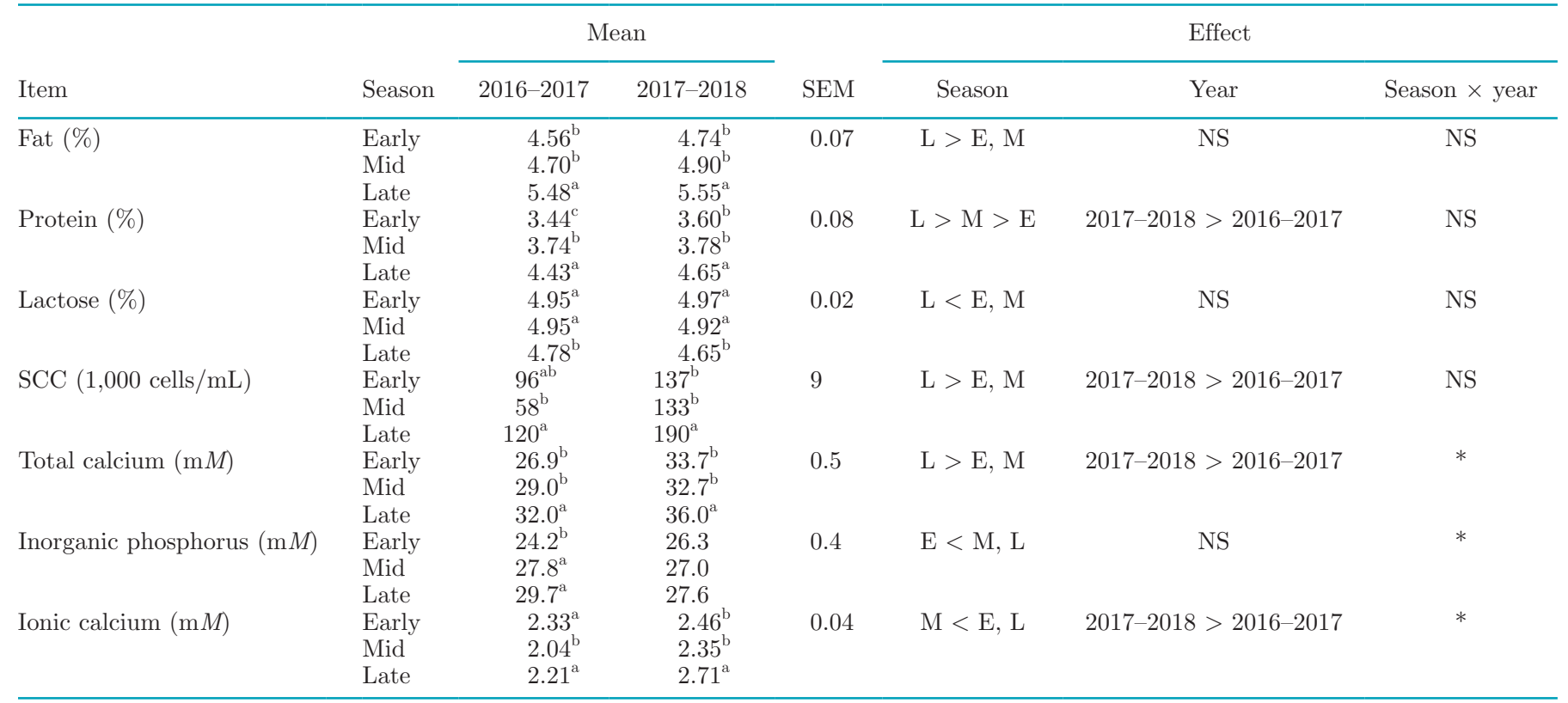

${ }^{\mathrm{a}-\mathrm{c}}$ Means of the same parameter within a column with different superscripts differ $(P<0.05)$.

${ }^{1} \mathrm{E}=$ early; $\mathrm{L}=$ late; $\mathrm{M}=$ mid.

${ }^{*} P<0.05$. 
Table 2. Raw milk physicochemical properties $(n=4-8 \text { for each parameter per season per year })^{1}$

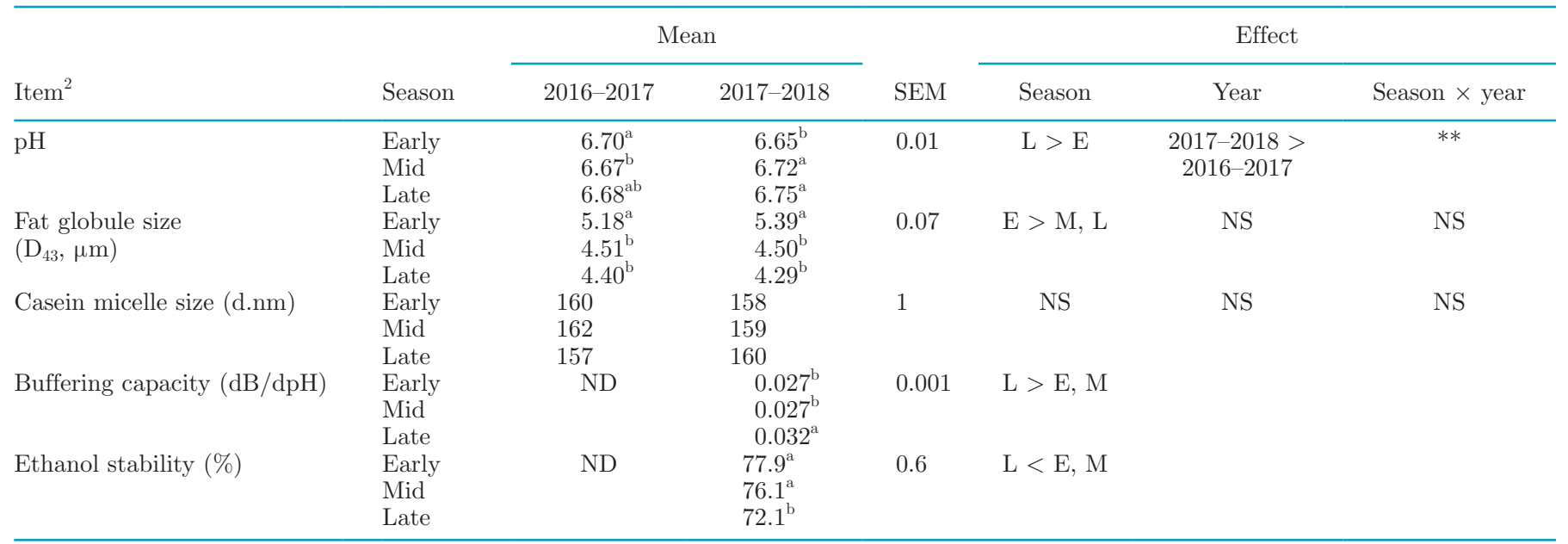

\footnotetext{
${ }^{\mathrm{a}, \mathrm{b}}$ Means of the same parameter within a column with different superscripts differ $(P<0.05)$.

${ }^{1} \mathrm{E}=$ early; $\mathrm{L}=$ late; $\mathrm{M}=$ mid; $\mathrm{ND}=$ not determined.

${ }^{2} \mathrm{D}_{43}=$ volume-weighted mean diameter; d.nm = diameter in nanometers; $\mathrm{dB} / \mathrm{dpH}=$ (volume of acid or base added $\times$ normality of acid or base/ (volume of sample $\times \mathrm{pH}$ change produced).

** $P<0.01$.
}

cium and calcium-binding anions such as phosphates and citrates greatly influences $\mathrm{Ca}^{2+}$ concentration in milk (Lewis, 2011).

\section{Physicochemical Properties}

Table 2 shows the seasonal variations in milk $\mathrm{pH}$, fat globule size, casein micelle size, buffering capacity, and ethanol stability. The $\mathrm{pH}$ displayed different seasonal trends in the 2 years $(2016-2017$, early season $>$ midseason; 2017-2018, early season $<$ mid-season and late season; $P<0.05$ ). The different SCC in the 2 years might account for the different patterns of variation in pH. Milk pH correlated with SCC $(P<0.05)$, which has been well documented (Auldist et al., 1995, 1996b; Kandeel et al., 2019). Similar to the current study, Albenzio et al. (2004) found that the $\mathrm{pH}$ of high-SCC ewe milk increased significantly in mid- and late lactation, whereas the $\mathrm{pH}$ of low-SCC ewe milk did not increase with SOL.

Milk fat globule sizes were largest in the early season. The patterns of variation were consistent during the 2 years and were in accordance with previous studies (Wiking et al., 2004; Huppertz and Kelly, 2006; Fleming et al., 2017). Wiking et al. (2004) found that the fat globule size correlated negatively with the diurnal fat yield of cows, suggesting that the lack of milk fat globule membrane materials relative to enhanced fat synthesis resulted in the increase in fat globule size. This may explain the seasonal trend in fat globule size we observed in the present study, considering that fat yield in milk reaches a maximum at about $60 \mathrm{~d}$ (i.e., around September-October in the early season).

Casein micelle size did not vary by season or year. This was in agreement with de Kruif and Huppertz (2012), who reported that the casein micelle size of milk from individual cows was stable during lactation. In a nonseasonal calving system in the United Kingdom, Chen et al. (2014) also reported that casein micelle size did not vary significantly by season.

Buffering capacity was highest in the late season. It correlated with the quantities of the major buffering constituents in milk, including protein $(P<0.01)$, calcium $(P<0.01)$, and inorganic phosphorus $(P<0.05)$.

Ethanol stability was lowest in the late season and correlated negatively with protein content, $\mathrm{Ca}^{2+}$ concentration, and calcium:inorganic phosphorus ratio $(P$ $<0.01$ ). It is expected that higher concentrations of protein, particularly casein, will lower ethanol stability by promoting aggregation among casein micelles. The negative correlation between ethanol stability and $\mathrm{Ca}^{2+}$ concentration was in accordance with previous studies (Horne and Parker, 1981; Lin et al., 2006). Ionic calcium could destabilize micelles by binding to caseins, reducing their negative charges (Horne and Parker, 1981). Both Donnelly and Horne (1986) and Tsioulpas et al. (2007) reported that the $\frac{\text { Calcium + Magnesium }}{\text { Phosphate + Citrate }}$ ratio correlated negatively with ethanol stability, similar to our findings for calcium:inorganic phosphorus ratio and ethanol stability. Those authors suggested that calcium and magnesium destabilized the casein micelles, where- 
Table 3. Protein composition (weight percentage in total protein) and degree of glycosylation of $\kappa$-CN ( $\mathrm{n}=5-8$ for each parameter per season per year $)^{1}$

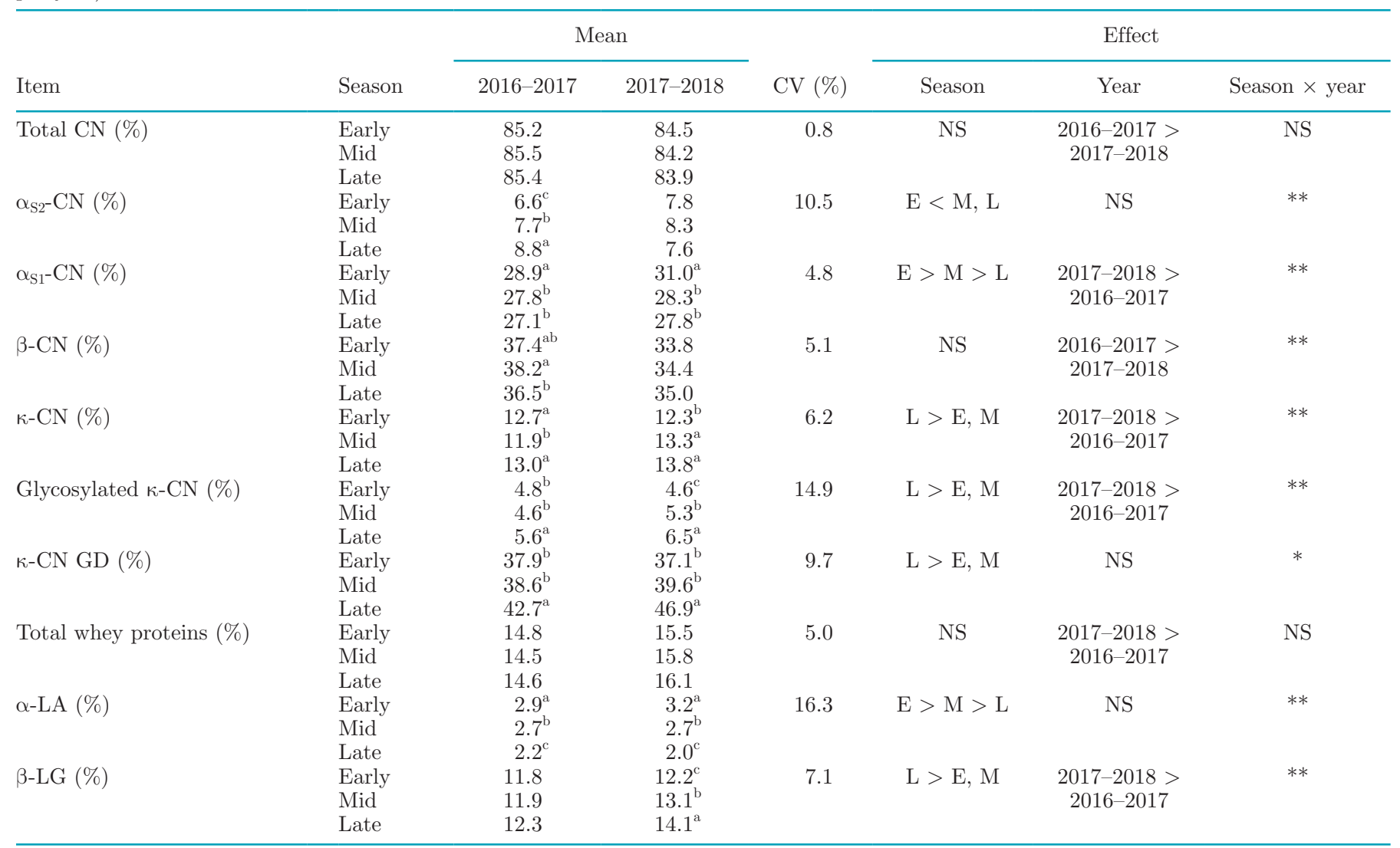

${ }^{\mathrm{a}-\mathrm{c}}$ Means of the same parameter within a column with different superscripts differ $(P<0.05)$.

${ }^{1} \mathrm{GD}=$ glycosylation degree; $\mathrm{E}=$ early; $\mathrm{L}=$ late; $\mathrm{M}=$ mid.

${ }^{*} P<0.05,{ }^{* *} P<0.01$.

as phosphate and citrate counteracted the destabilizing effect by lowering their activity.

\section{Protein Composition}

Total Casein and WP. Table 3 shows the relative concentrations in total protein of total casein, total whey protein, individual proteins, and the GD of $\kappa-\mathrm{CN}$. The proportion of casein in total protein did not vary by season but was lower in 2017-2018 than in 2016-2017.

The low SCC (Table 1) of the seasonal milk in this study, and thus the good overall health of the cow udders, might be reason for the stable ratio of casein to protein across the different seasons. In agreement with the current study, several authors have found that the proportion of casein did not vary over lactation (Walstra and Jenness, 1984; Auldist et al., 1998; Coulon et al., 1998), although other authors have reported a lower proportion of casein in late-lactation milk (Ng-KwaiHang et al., 1982; Auldist et al., 1996a; Lucey, 1996). The differences in milk SCC in these studies might be the main reason for this discrepancy. Unlike the contradicting reports on the effect of SOL on the proportion of casein, a higher SCC has been consistently related to a lower percentage of casein in the total protein $(\mathrm{Ng}$ Kwai-Hang et al., 1982; Auldist et al., 1995; Coulon et al., 1998). Two factors related to SCC have been suggested to account for the change in casein:total protein ratio in late-lactation milk: enhanced influx of plasma proteins through ruptured mammary epithelia and higher levels of enzymatic breakdown of the caseins by proteases (Donnelly and Barry, 1983; Auldist et al., 1996a; Lucey, 1996). Coulon et al. (1998) reported that the casein:protein ratio significantly reduced with SCC only when SCC was $>200,000$ cells $/ \mathrm{mL}$. This might explain the nonsignificant seasonal variation in the proportion of total casein in this study, considering that none of the seasonal milk samples had an SCC $>200,000$ cells $/ \mathrm{mL}$.

However, the higher SCC in 2017-2018 might have contributed to the higher proportion of whey proteins (particularly $\beta-\mathrm{LG}$ ) than in 2016-2017, considering 
Table 4. Heat-induced decrease in ionic calcium $(n=4-8 \text { for each parameter per season per year })^{1}$

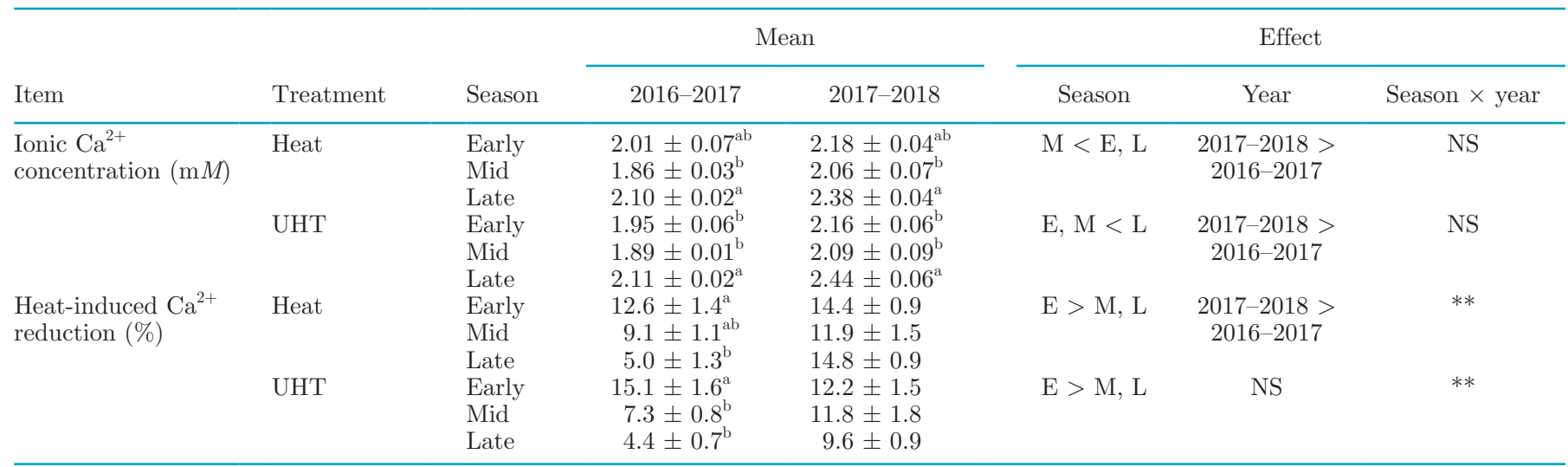

${ }^{\mathrm{a}, \mathrm{b}}$ Means of the same parameter within a column with different superscripts differ $(P<0.05)$.

${ }^{1} \mathrm{Ca}^{2+}=$ ionic calcium; $\mathrm{E}=$ early; Heat $=90^{\circ} \mathrm{C}$ for $6 \mathrm{~min} ; \mathrm{L}=$ late; $\mathrm{M}=\operatorname{mid}$; UHT $=140^{\circ} \mathrm{C}$ for $5 \mathrm{~s}$.

$* * P<0.01$.

that the between-year difference in SCC was greater than that within each year (Table 1 ). In addition, the higher environmental temperature in 2017-2018 might have caused heat stress and a decline in casein synthesis (Bernabucci et al., 2002; Bertocchi et al., 2014).

Individual Proteins and Glycosylation of $\kappa-C N$. The percentages of all individual proteins were significantly affected by season $\times$ year interactions, suggesting that the seasonal variation patterns were different during the 2 years. However, we observed the same seasonal trends during the 2 years for $\alpha_{\mathrm{s} 1^{-}}$ CN (early season $>$ mid-season and late season), $\alpha-\mathrm{LA}$ (early season $>$ mid-season $>$ late season), and the GD of $\kappa$-CN (late season $>$ early season and mid-season). Interestingly, the concentrations of G-k-CN (CV 14.9\%) and $\alpha-\mathrm{LA}$ (CV 16.3\%) also varied the most among all milk proteins across the seasons (Table 3 ). The stable seasonal trends and large variations in $\mathrm{G}-\kappa-\mathrm{CN}$ and $\alpha$-LA are discussed below.

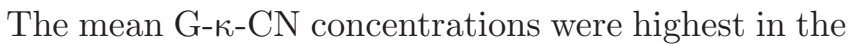
late season in both years. This was because both the mean concentration of total $\kappa-\mathrm{CN}$ and the GD of $\kappa-\mathrm{CN}$ were highest in the late season. O'Connell et al. (2017) reported higher total $\kappa-\mathrm{CN}$ in late lactation than in mid-lactation, whereas Barry and Donnelly (1980) reported no significant difference in $\mathrm{\kappa}$ - $\mathrm{CN}$ during different SOL. The $\kappa-\mathrm{CN}$ GD reached a maximum in the late season in both years, in agreement with reported trends during the lactation cycle (Robitaille et al., 1991; Bonfatti et al., 2014).

The decrease in relative concentration of $\alpha$-LA during the season was consistent with the change during lactation (Regester and Smithers, 1991; Ostersen et al., 1997). The $\alpha$-LA concentration correlated with lactose content $(P<0.01)$, which was also observed by Heck et al. (2009) in a nonseasonal calving system. The role of $\alpha$-LA as a coenzyme in lactose synthesis probably gave rise to this correlation (Brew, 2003).

\section{Heat-Induced Changes in Seasonal Milk}

Ionic Calcium. The trends in seasonal and between-year variations in the $\mathrm{Ca}^{2+}$ concentration of milk heated under both conditions $\left(90^{\circ} \mathrm{C}\right.$ for $6 \mathrm{~min}$ and UHT treatment) were broadly consistent with those in raw milk (Table 4). We found strong correlations among $\mathrm{Ca}^{2+}$ concentrations in raw milk, heated $\left(90^{\circ} \mathrm{C}\right.$ for 6 min) milk, and UHT milk $(P<0.01)$.

Heating at $90^{\circ} \mathrm{C}$ for $6 \mathrm{~min}$ and UHT treatment resulted in significant decreases in $\mathrm{Ca}^{2+}$ concentration compared with raw milk $(P<0.05)$. The extent of heat-induced $\mathrm{Ca}^{2+}$ reduction was similar for the 2 heating conditions $(P>0.05)$. The season $\times$ year interactions were significant for the $\mathrm{Ca}^{2+}$ decrease under both heat treatments. In 2016-2017, the heat-induced decrease in $\mathrm{Ca}^{2+}$ was significantly higher in the early season than during the rest of the year. However, in 2017-2018, we found no significant seasonal variation. A possible explanation for the between-year difference was that $\mathrm{Ca}^{2+}$ was considerably higher in 2017-2018 than in 2016-2017 (Table 1). Consequently, the mean $\mathrm{Ca}^{2+}$ reduction during heating was higher in 2017-2018 $(P<0.05)$, making the variation among seasons less apparent.

Serum-Phase $\kappa-C N$ and Heat-Induced $\kappa-C N$ Dissociation. Figure 1 depicts the percentages of serum-phase $\kappa-\mathrm{CN}$ in the total $\kappa-\mathrm{CN}$ of raw milk and heated milk. In raw milk, the percentages of serumphase $\kappa$-CN were comparable with those reported by Singh and Latham (1993) and Singh et al. (1996). In 
both years, the proportion of serum-phase $\kappa-\mathrm{CN}$ increased significantly as the milking season progressed.

Both heating conditions resulted in significant dissociation of $\kappa-\mathrm{CN}(P<0.05)$. We found that UHT milk had a considerably higher amount of serum-phase k-CN $(33.3 \pm 1.3 \%)$ than milk heated at $90^{\circ} \mathrm{C}$ for 6 min $(15.1 \pm 0.7 \%)$. We found no significant seasonal variation in serum-phase $\mathrm{k}-\mathrm{CN}$ after either heat treatment. For the between-year variation, heated milk $\left(90^{\circ} \mathrm{C}\right.$ for 6 min) from 2016-2017 had a higher level of serum-phase א-CN than milk from 2017-2018. A possible explanation might be that milk from 2017-2018 had a higher calcium:inorganic phosphorus ratio (Table 1); a higher proportion of calcium relative to phosphate has been reported to reduce the dissociation of $\kappa-\mathrm{CN}$ (Singh and Fox, 1987).

Serum-Phase $\kappa-C N$ Glycosylation. To describe how the glycosylation of $\kappa$-CN affected its partitioning between the micelles and the serum phase, the serum: milk ratio of $\kappa-\mathrm{CN}$ GD is shown in Figure 2. In raw milk, the mean serum:milk $\kappa-\mathrm{CN}$ GD ratio was $0.71 \pm$ 0.03 , indicating that a higher proportion of NG- $\kappa-C N$

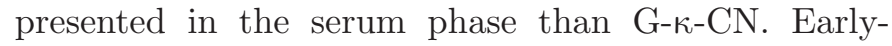
season milk serum contained a significantly higher proportion of G-k-CN than serum in the rest of the year, regardless of the fact that the GD of total $\kappa-\mathrm{CN}$ in the milk was highest in the late season and low in the early season (Table 3). The GD of $\kappa-\mathrm{CN}$ in the milk correlated with a lower serum:milk GD ratio $(r=-0.762$, $P<0.01$ ). These results suggested that the natural

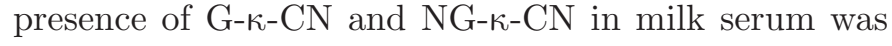

independent of the $\kappa$-CN GD of the milk, or even that a higher $\kappa$-CN GD might somehow contribute to lowering the proportion of G- $\kappa-\mathrm{CN}$ in the serum phase. The mechanism of this phenomenon is unclear.

Heat treatments, particularly UHT treatment, resulted in a greater proportion of G-א-CN in the serum phase. The mean serum:milk GD ratios were $0.83 \pm$ 0.02 in heated milk $\left(90^{\circ} \mathrm{C}\right.$ for $\left.6 \mathrm{~min}\right)$ and $1.06 \pm 0.01$ in UHT milk. With heating at $90^{\circ} \mathrm{C}$ for $6 \mathrm{~min}$, dissociation of NG-k-CN was still favored, as in raw milk, but proportionally more G- $\kappa-\mathrm{CN}$ was present in the serum. However, in UHT milk, the extent of dissociation of

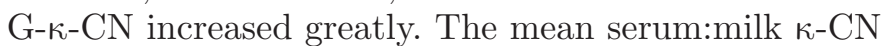
GD ratio of UHT milk was $>1.0$, indicating that the dissociation of G-k-CN was favored, in contrast to that of raw milk and heated milk $\left(90^{\circ} \mathrm{C}\right.$ for $\left.6 \mathrm{~min}\right)$. The UHT treatment seemed to trigger significant dissociation of G-k-CN, which could not be attained under heating at $90^{\circ} \mathrm{C}$ for 6 min. This might also explain the significantly higher extent of $\mathrm{k}$-CN dissociation in UHT milk (Figure 1). These results suggest that the mechanism of heat-induced $\kappa$-CN dissociation might be different under different heating conditions, in which the glycosylation of $\kappa$-CN plays a role.

Milk heated under both conditions followed similar seasonal patterns to that of raw milk in terms of serum: milk $\kappa$-CN GD ratio, despite the marked effect of heating on $\kappa-\mathrm{CN}$ dissociation. The proportion of $\mathrm{G}-\kappa-\mathrm{CN}$ in the serum phase generally decreased as the milking season progressed in both types of heated milk. Under

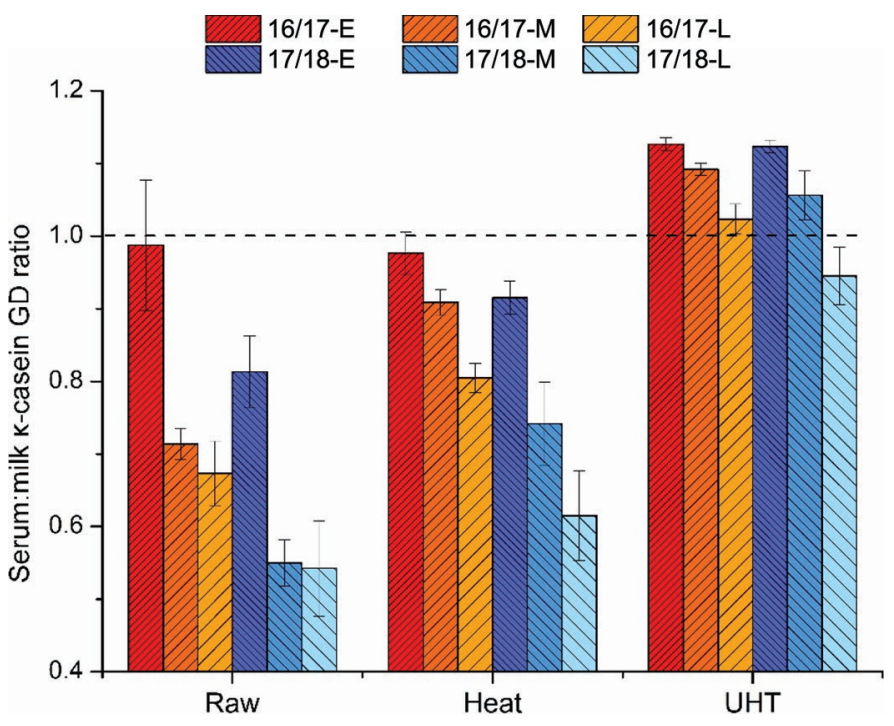

Figure 2. Serum-to-milk ratios of degree of glycosylation (GD) of $\kappa$-CN. Heat, $90^{\circ} \mathrm{C}$ for $6 \mathrm{~min}$; UHT, $140^{\circ} \mathrm{C}$ for $5 \mathrm{~s}$. Dashed line indicates ratio of $1.0 ; \mathrm{n}=3-8$ for each parameter per season $(\mathrm{E}=$ early; $\mathrm{L}=$ late; $\mathrm{M}=$ mid) per year $(2016-2017,16 / 17 ; 2017-2018,17 / 18)$. Error bars represent SE.
Figure 1. Percentage of serum-phase $\kappa-\mathrm{CN}$ in total $\kappa-\mathrm{CN}$ of milk Heat, $90^{\circ} \mathrm{C}$ for $6 \mathrm{~min}$; UHT, $140^{\circ} \mathrm{C}$ for $5 \mathrm{~s}$; $\mathrm{n}=3-8$ for each parameter per season ( $\mathrm{E}=$ early; $\mathrm{L}=$ late; $\mathrm{M}=$ mid) per year $(2016-2017,16 / 17$; 2017-2018, 17/18). Error bars represent SE. 
both heating conditions, late-season milk, with the highest $\kappa$-CN GD, still had the lowest proportion of G-k-CN in the serum phase. Nevertheless, the effect of heating was evident, considering that the extent of variation in the serum:milk $\kappa-\mathrm{CN}$ GD ratio was lowest in UHT milk (CV $7.2 \%)$, followed by heated $\left(90^{\circ} \mathrm{C}\right.$ for 6 min) milk (CV 15.9\%), and was highest in raw milk (CV 24.1\%). In particular, the serum:milk GD ratio of late-season milks had the largest increase from raw and heated $\left(90^{\circ} \mathrm{C}\right.$ for $\left.6 \mathrm{~min}\right)$ milks to UHT milk. This could be explained by our hypothesis that UHT conditions triggered the dissociation of G- $\kappa-\mathrm{CN}$ and the fact that late-season milk had the highest $\kappa$-CN GD among the different seasons.

When we compared the 2 years, both raw milk and heated $\left(90^{\circ} \mathrm{C}\right.$ for $\left.6 \mathrm{~min}\right)$ milk had higher serum:milk к-CN GD ratios in 2016-2017 than in 2017-2018, but we found no significant difference for UHT milk. The

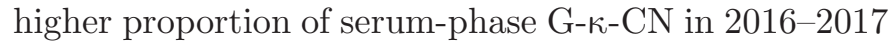
may have been associated with the higher $\kappa-\mathrm{CN}$ GD of the milk in 2017-2018 than in 2016-2017, although the between-year difference of the latter was not significant $(P=0.052)$.

Heat-Induced WP Denaturation and Association with Casein Micelles. As shown in Figure 3, heating at $90^{\circ} \mathrm{C}$ for 6 min and UHT treatment resulted in similar extents of whey protein denaturation. However, the fraction of micelle-bound whey proteins was significantly higher in heated $\left(90^{\circ} \mathrm{C}\right.$ for $\left.6 \mathrm{~min}\right)$ milk than in UHT milk. The differences in heating rate and the dissociation of $\kappa$-CN might account for the different extents of whey protein-casein micelle association. Oldfield et al. (1998) suggested that whey protein-casein micelle association was more favored under slower heating conditions, compared with rapid heating conditions, such as the UHT treatment used in this study. In addition, UHT treatment induced a considerably higher extent of $\kappa$-CN dissociation (Figure 1), which was reported to correlate with a higher proportion of serum-phase denatured whey proteins in heated milk (Anema and Li, 2003; Singh, 2004). This dissociated $\kappa-\mathrm{CN}$ could form complexes with denatured whey proteins in the serum phase, competing with $\kappa-\mathrm{CN}$ on the micelle surface.

The extent of whey protein denaturation was lowest in the early season for heated $\left(90^{\circ} \mathrm{C}\right.$ for 6 min) milk $(P$ $<0.05)$ but did not vary by season in UHT milk $(P$ $>0.05)$. Nevertheless, the extents of whey protein-casein micelle association were highest in the late season $(P<0.05)$ under both heat treatments. This agreed with Auldist et al. (1996b) and Oldfield (1996), who reported that late-lactation milk contained a higher amount of denatured whey proteins complexed with the casein micelles than milk produced in earlier stages of lactation. When we compared the 2 years, heated $\left(90^{\circ} \mathrm{C}\right.$ for $6 \mathrm{~min}$ ) milk in 2017-2018 had a greater extent of whey protein-casein micelle association than milk in 2016-2017, although we found no significant difference in whey protein denaturation.

Three factors might have contributed to the seasonal and between-year variations in the denaturation of whey proteins and their association with casein micelles: the proportion of $\beta-\mathrm{LG}$ in the total WP, the extent of dissociation of $\kappa-\mathrm{CN}$, and $\mathrm{Ca}^{2+}$ concentration.

The proportion of $\beta-\mathrm{LG}$ in the total whey proteins increased as the milking season progressed, and was higher in 2017-2018 than in 2016-2017. It correlated with the denaturation of the whey proteins and their
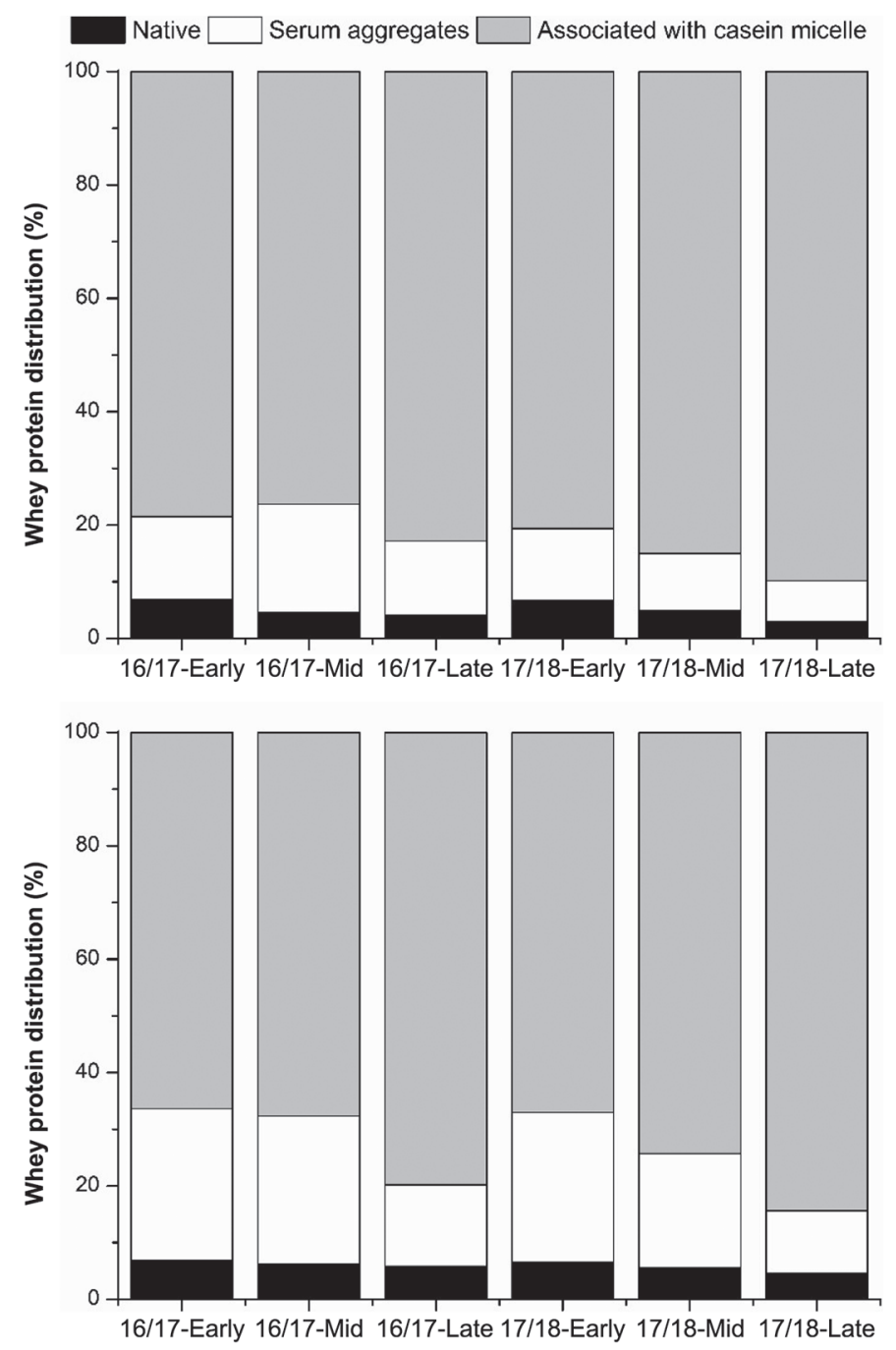

Figure 3. Whey protein distribution in milk heated at $90^{\circ} \mathrm{C}$ for 6 min (top) and UHT milk (bottom). Fractions of whey proteins that remained native, formed aggregates in the serum, and associated with the casein micelles are shown as black, white, and gray bars, respectively; $\mathrm{n}=3-8$ for each parameter per season per year (2016-2017, $16 / 17 ; 2017-2018,17 / 18)$. 
association with the casein micelles under both heating conditions $(P<0.05)$. Not only is $\beta-\mathrm{LG}$ the main type of whey protein involved in forming complexes with $\kappa-\mathrm{CN}$, but it also catalyzes the irreversible denaturation of $\alpha$-LA by forming disulfide bonds. Thus, a higher proportion of $\beta-\mathrm{LG}$ in the whey proteins would promote the denaturation of the total whey proteins and their association with the casein micelles. Oldfield (1996) also attributed the high WP denaturation and extent of association with the casein micelles in lateseason New Zealand milk to its higher content of $\beta-\mathrm{LG}$ and therefore more free thiol groups.

As discussed previously, serum-phase $\kappa-\mathrm{CN}$ could form complexes with denatured whey proteins, competing with $\kappa$-CN on the micelle surface, and could consequently lower the extent of the association of whey proteins with casein micelles. We found that in heated $\left(90^{\circ} \mathrm{C}\right.$ for $\left.6 \mathrm{~min}\right)$ milk, the percentage of serum-phase $\kappa-\mathrm{CN}$ correlated negatively with whey protein-casein micelle association $(P<0.01)$. This may explain the between-year variation: milk in 2017-2018 had less serum-phase $\kappa-\mathrm{CN}$ and a greater association of whey proteins with casein micelles $(P<0.05)$.

The $\mathrm{Ca}^{2+}$ concentration correlated positively with whey protein-casein micelle association under both heating conditions $(P<0.01)$. By binding to milk proteins, $\mathrm{Ca}^{2+}$ may reduce their negative charges and promote aggregation among the proteins (Donovan and Mulvihill, 1987). Law and Leaver (2000) reported that the addition of $\mathrm{CaCl}_{2}$ to skim milk resulted in greater denaturation of the whey proteins and their association with the casein micelles.

Casein Micelle Size. Both heating conditions resulted in a significant increase in casein micelle size (Figure $4, P<0.05$ ). The UHT milk had larger micelle size $(207 \pm 1 \mathrm{~nm})$ than milk heated at $90^{\circ} \mathrm{C}$ for $6 \mathrm{~min}$ $(169 \pm 1 \mathrm{~nm})$. The association between denatured whey proteins and casein micelles has been well demonstrated as the major contributor to the heat-induced increase in casein micelle size in milk heated at under $100^{\circ} \mathrm{C}$ (Anema and Li, 2003; Anema, 2007). The present study found that UHT milk had a larger micelle size than heated $\left(90^{\circ} \mathrm{C}\right.$ for $\left.6 \mathrm{~min}\right)$ milk, despite the lesser whey protein-casein micelle association. This suggested that, in UHT milk, mechanisms other than whey proteincasein micelle association played an important role in altering the casein micelle size. Aggregation among the partially $\kappa$-CN-depleted micelles might be the main cause for the greater increase in casein micelle size in UHT milk.

As discussed previously, UHT treatment induced a considerably higher level of $\kappa$-CN dissociation $(33.3 \pm$ $1.3 \%)$ than heated $\left(90^{\circ} \mathrm{C}\right.$ for 6 min $)$ milk $(15.1 \pm 0.7 \%)$. Partially $\kappa$-CN-depleted casein micelles are prone to

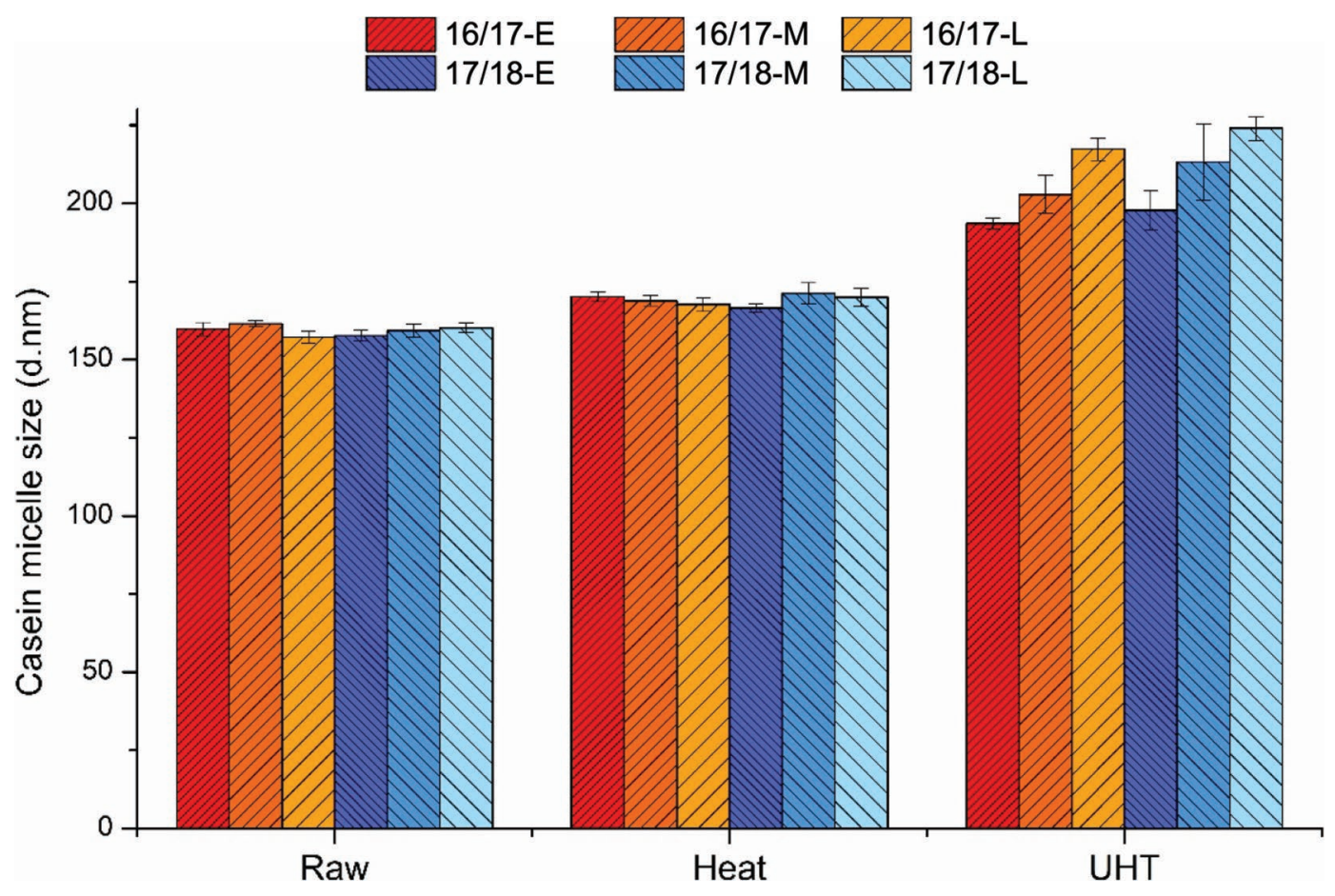

Figure 4. Mean hydrodynamic diameter of casein micelles in raw and heated milk. Heat, $90^{\circ} \mathrm{C}$ for 6 min; UHT, $140^{\circ} \mathrm{C}$ for $5 \mathrm{~s} ; \mathrm{n}=4-8$ for each parameter per season ( $\mathrm{E}=$ early; $\mathrm{L}=$ late; $\mathrm{M}=$ mid) per year $(2016-2017,16 / 17 ; 2017-2018,17 / 18)$. d.nm = diameter in nanometers. Error bars represent SE. 
aggregation in the presence of $\mathrm{Ca}^{2+}$ (Singh, 2004). Gaur et al. (2018) reported that sediment in UHT milk was mainly composed of $\kappa$-CN-depleted casein micelles, whose quantity increased with increasing level of ionic calcium. We propose that UHT treatment, because of its stronger $\kappa-\mathrm{CN}$ depletion effect, might have induced aggregation among part of the casein micelles, resulting in the increase in average casein micelle size. In contrast, in milk heated at $90^{\circ} \mathrm{C}$ for 6 min, aggregation among the micelles was negligible and the increase in the casein micelle size was likely to result from the association with whey proteins.

Seasonality had different effects on heated $\left(90^{\circ} \mathrm{C}\right.$ for 6 min) milk and UHT milk. In heated milk, we found no significant seasonal or between-year variation in casein micelle size. This indicated that the seasonal variations in the extent of whey protein-casein micelle association, although statistically significant, were not sufficient to induce a significant change in casein micelle size. This was reasonable considering the overall high extent of the heating-induced whey protein-casein micelle association of $81.6 \pm 1.0 \%$.

In UHT milk, the casein micelle size was significantly larger in the late season than in the early season in both years $(P<0.05)$. Based on the hypothesis above, the extent of aggregation among the partially $\kappa-\mathrm{CN}-$ depleted casein micelles possibly determined the increase in casein micelle size in the UHT milk. We propose that seasonal milk containing greater amounts of protein, serum-phase $\kappa_{-} \mathrm{CN}$, and $\mathrm{Ca}^{2+}$ may favor aggregation among the casein micelles. The casein micelle size of the UHT milk correlated strongly with both the protein content and the serum-phase $\kappa-\mathrm{CN}$ content of the raw milk $(P<0.01)$. A higher protein content presumably accelerated the rate of aggregation. Raw milk with a higher proportion of serum-phase $\kappa-\mathrm{CN}$, and thus lower a proportion of $\kappa$-CN on the micelle surface, would more readily reach the critical level of $\kappa$-CN depletion during heating that leads to significant aggregation among the casein micelles. Consequently, in milk with a higher serum-phase $\kappa-\mathrm{CN}$ content, more casein micelles may reach this critical level of $\kappa$-CN depletion during heating, and this critical level may be reached earlier, allowing more time for aggregation among the partially $\kappa$-CN-depleted micelles. The insignificant positive correlation $(P=0.055)$ between the $\mathrm{Ca}^{2+}$ concentration and the casein micelle size might have been confounded by the fact that early-season milk had the lowest protein content and serum-phase $\kappa-\mathrm{CN}$ content but a high $\mathrm{Ca}^{2+}$ concentration. If the aggregation of some $\kappa$-CN-depleted casein micelles indeed caused the observed increases in the average micelle size induced by UHT treatment, it would be interesting to look at whether the sedimentation in UHT milk reported by Gaur et al. (2018) has a seasonal variation pattern similar to that of the casein micelle size of UHT milk in this study.

\section{CONCLUSIONS}

This study adds to the evidence that the SOL largely controls the seasonal variations in the composition and physicochemical properties of milk in a seasonal calving system. Despite significant between-year effects on some milk characteristics, fat, protein, and lactose content, fat globule size, and G- $\kappa-\mathrm{CN}$ and $\alpha-\mathrm{LA}$ concentrations had consistent seasonal variation patterns, similar to those during the lactation cycle. For the first time, we highlighted the variation in $\kappa$-CN glycosylation in a seasonal milk study. Two typical heat treatments of milk, heating at $90^{\circ} \mathrm{C}$ for 6 min and UHT treatment, resulted in significantly different extents of $\kappa-\mathrm{CN}$ dissociation (particularly G- $\kappa-\mathrm{CN}$ ) and whey protein-casein micelle association, and different increases in casein micelle size. In particular, UHT treatment might have triggered significant dissociation of G- $\kappa-\mathrm{CN}$ and subsequent aggregation among the casein micelles. Seasonality affected the heat-induced protein dissociation and association, possibly because of the differences across the seasons in the GD of $\kappa-\mathrm{CN}$, the protein composition, and the $\mathrm{Ca}^{2+}$ concentration of the milk. This information will contribute to an understanding and control of the processing properties of milk and the quality of dairy products throughout the year.

\section{ACKNOWLEDGMENTS}

This study was funded by Callaghan Innovation (Wellington, New Zealand). The authors thank Massey University No. 4 dairy farm for providing access to the SCC data. We thank Claire Woodhall (Havelock North, New Zealand) for proofreading the manuscript.

\section{REFERENCES}

Albenzio, M., M. Caroprese, A. Santillo, R. Marino, L. Taibi, and A. Sevi. 2004. Effects of somatic cell count and stage of lactation on the plasmin activity and cheese-making properties of ewe milk. J. Dairy Sci. 87:533-542.

Anema, S. G. 2007. Role of $\kappa$-casein in the association of denatured whey proteins with casein micelles in heated reconstituted skim milk. J. Agric. Food Chem. 55:3635-3642.

Anema, S. G., and H. Klostermeyer. 1997. Heat-induced, pH-dependent dissociation of casein micelles on heating reconstituted skim milk at temperatures below $100^{\circ}$ C. J. Agric. Food Chem. 45:1108 1115.

Anema, S. G., and Y. Li. 2003. Association of denatured whey proteins with casein micelles in heated reconstituted skim milk and its effect on casein micelle size. J. Dairy Res. 70:73-83.

Auldist, M., S. Coats, G. Rogers, and G. Mcdowell. 1995. Changes in the composition of milk from healthy and mastitic dairy cows during the lactation cycle. Anim. Prod. Sci. 35:427-436. 
Auldist, M. J., S. Coats, B. J. Sutherland, J. J. Mayes, G. H. Mcdowell, and G. L. Rogers. 1996a. Effects of somatic cell count and stage of lactation on raw milk composition and the yield and quality of Cheddar cheese. J. Dairy Res. 63:269-280. https://doi.org/ 10.1017/S0022029900031769.

Auldist, M. J., S. J. Coats, B. J. Sutherland, J. F. Hardham, G. H. Mcdowell, and G. L. Rogers. 1996b. Effect of somatic cell count and stage of lactation on the quality and storage life of ultra high temperature milk. J. Dairy Res. 63:377-386.

Auldist, M. J., B. J. Walsh, and N. A. Thomson. 1998. Seasonal and lactational influences on bovine milk composition in New Zealand. J. Dairy Res. 65:401-411.

Barłowska, J., Z. Litwińczuk, and M. Kowal. 2014. Influence of production season and lactation stage on the technological suitability of milk from cows of various breeds fed in the TMR system. Ann. Anim. Sci. https://doi.org/10.2478/aoas-2014-0039.

Barry, J. G., and W. J. Donnelly. 1980. Casein compositional studies: 1. The composition of casein from Friesian herd milks. J. Dairy Res. 47:71-81.

Bernabucci, U., N. Lacetera, B. Ronchi, and A. Nardone. 2002. Effects of the hot season on milk protein fractions in Holstein cows. Anim. Res. 51:25-33.

Bertocchi, L., A. Vitali, N. Lacetera, A. Nardone, G. Varisco, and U. Bernabucci. 2014. Seasonal variations in the composition of Holstein cow's milk and temperature-humidity index relationship. Animal 8:667-674.

Bijl, E., R. De Vries, H. Van Valenberg, T. Huppertz, and T. Van Hooijdonk. 2014. Factors influencing casein micelle size in milk of individual cows: genetic variants and glycosylation of $\kappa$-casein. Int. Dairy J. 34:135-141.

Bobe, G., D. C. Beitz, A. E. Freeman, and G. L. Lindberg. 1998. Separation and quantification of bovine milk proteins by reversed-phase high-performance liquid chromatography. J. Agric. Food Chem. 46:458-463.

Bonfatti, V., G. Chiarot, and P. Carnier. 2014. Glycosylation of k-casein: Genetic and nongenetic variation and effects on rennet coagulation properties of milk. J. Dairy Sci. 97:1961-1969.

Brew, K. 2003. $\alpha$-Lactalbumin. Pages 387-419 in Advanced Dairy Chemistry -1 Proteins. 3rd ed. P. F. Fox and P. L. H. McSweeney, ed. Springer, Heidelberg, Germany.

Chen, B., M. J. Lewis, and A. S. Grandison. 2014. Effect of seasonal variation on the composition and properties of raw milk destined for processing in the UK. Food Chem. 158:216-223. https://doi .org/10.1016/j.foodchem.2014.02.118.

Coulon, J.-B., C. Hurtaud, B. Remond, and R. Verite. 1998. Factors contributing to variation in the proportion of casein in cows' milk true protein: A review of recent INRA experiments. J. Dairy Res. 65:375-387.

de Kruif, C. G., and T. Huppertz. 2012. Casein micelles: Size distribution in milks from individual cows. J. Agric. Food Chem. 60:4649-4655

Donato, L., and F. Guyomarc'h. 2009. Formation and properties of the whey protein/ $\kappa$-casein complexes in heated skim milk-A review. Dairy Sci. Technol. 89:3-29.

Donato, L., F. Guyomarc'h, S. Amiot, and D. G. Dalgleish. 2007. Formation of whey protein/ $\kappa$-casein complexes in heated milk: Preferential reaction of whey protein with $\kappa$-casein in the casein micelles. Int. Dairy J. 17:1161-1167.

Donnelly, W. J., and J. G. Barry. 1983. Casein compositional studies. III. Changes in Irish milk for manufacturing and role of milk proteinase. J. Dairy Res. 50:433-441.

Donnelly, W. J., and D. S. Horne. 1986. Relationship between ethanol stability of bovine milk and natural variations in milk composition. J. Dairy Res. 53:23-33.

Donovan, M., and D. Mulvihill. 1987. Thermal denaturation and aggregation of whey proteins. Irish J. Food Sci. Technol. 11:87-100.

Fleming, A., F. Schenkel, J. Chen, F. Malchiodi, R. Ali, B. Mallard, M. Sargolzaei, M. Corredig, and F. Miglior. 2017. Variation in fat globule size in bovine milk and its prediction using mid-infrared spectroscopy. J. Dairy Sci. 100:1640-1649.
Fox, P. 2009. Lactose: Chemistry and properties. Pages 1-15 in Advanced Dairy Chemistry - 3 Lactose, Salts, Water and Minor Constituents. 3rd ed. P. L. H. McSweeney and P. F. Fox, ed. Springer, Heidelberg, Germany.

Fox, P. F., and P. L. McSweeney. 1998. Dairy Chemistry and Biochemistry. Blackie Academic \& Professional, London, UK.

Gaur, V., J. Schalk, and S. G. Anema. 2018. Sedimentation in UHT milk. Int. Dairy J. 78:92-102.

Geerts, J., J. Bekhof, and J. Scherjon. 1983. Determination of calcium ion activities in milk with an ion-selective electrode. A linear relationship between the logarithm of time and the recovery of the calcium ion activity after heat treatment. Neth. Milk Dairy J. $37: 197-211$

Grimley, H., A. Grandison, and M. Lewis. 2009. Changes in milk composition and processing properties during the spring flush period. Dairy Sci. Technol. 89:405-416.

Grufferty, M., and D. Mulvihill. 1987. Proteins recovered from milks heated at alkaline $\mathrm{pH}$ values. Int. J. Dairy Technol. 40:82-85.

Heck, J. M., H. J. Van Valenberg, J. Dijkstra, and A. C. Van Hooijdonk. 2009. Seasonal variation in the Dutch bovine raw milk composition. J. Dairy Sci. 92:4745-4755. https://doi.org/10.3168/jds .2009-2146.

Horne, D. S., and T. G. Parker. 1981. Factors affecting the ethanol stability of bovine milk.: I. Effect of serum phase components. J. Dairy Res. 48:273-284.

Huppertz, T., S. Grosman, P. F. Fox, and A. L. Kelly. 2004. Heat and ethanol stabilities of high-pressure-treated bovine milk. Int. Dairy J. $14: 125-133$

Huppertz, T., and A. Kelly. 2006. Physical chemistry of milk fat globules. Pages 173-212 In Advanced Dairy Chemistry - 2 Lipids. 3rd ed. P. F. Fox and P. L. H. McSweeney, ed. Springer, Heidelberg, Germany.

Igono, M. O., H. D. Johnson, B. J. Steevens, W. A. Hainen, and M. D. Shanklin. 1988. Effect of season on milk temperature, milk growth hormone, prolactin, and somatic cell counts of lactating cattle. Int. J. Biometeorol. 32:194-200.

Kandeel, S. A., A. A. Megahed, M. H. Ebeid, and P. D. Constable. 2019. Ability of milk $\mathrm{pH}$ to predict subclinical mastitis and intramammary infection in quarters from lactating dairy cattle. J. Dairy Sci. 102:1417-1427.

Law, A. J., and J. Leaver. 2000. Effect of $\mathrm{pH}$ on the thermal denaturation of whey proteins in milk. J. Agric. Food Chem. 48:672-679.

Lewis, M. J. 2011. The measurement and significance of ionic calcium in milk-A review. Int. J. Dairy Technol. 64:1-13.

Lin, M. J., M. Lewis, and A. Grandison. 2006. Measurement of ionic calcium in milk. Int. J. Dairy Technol. 59:192-199.

Lindmark-Månsson, H., R. Fondén, and H.-E. Pettersson. 2003. Composition of Swedish dairy milk. Int. Dairy J. 13:409-425.

Lucey, J. A. 1996. Cheesemaking from grass based seasonal milk and problems associated with late-lactation milk. Int. J. Dairy Technol. 49:59-64.

McMahon, D. J. 1996. Age-gelation of UHT milks: Changes that occur during storage, their effect on shelf life and the mechanism by which age-gelation occurs. Pages $315-326$ in Heat Treatments and Alternative Methods. International Dairy Federation, Brussels, Belgium.

Ng-Kwai-Hang, K. F., J. F. Hayes, J. E. Moxley, and H. G. Monardes. 1982. Environmental influences on protein content and composition of bovine milk. J. Dairy Sci. 65:1993-1998.

Ng-Kwai-Hang, K. F., J. F. Hayes, J. E. Moxley, and H. G. Monardes. 1984. Variability of test-day milk production and composition and relation of somatic cell counts with yield and compositional changes of bovine milk. J. Dairy Sci. 67:361-366. https://doi.org/ 10.3168/jds.S0022-0302(84)81309-0.

O'Brien, B., and T. P. Guinee. 2011. Seasonal effects on processing properties of cows' milk. Pages 598-606 in Encyclopedia of Dairy Sciences. 2nd ed. J. W. Fuquay, P. F. Fox, and P. L. H. McSweeney, ed. Academic Press, San Diego, CA. 
O'Connell, A., A. Kelly, J. Tobin, P. Ruegg, and D. Gleeson. 2017. The effect of storage conditions on the composition and functional properties of blended bulk tank milk. J. Dairy Sci. 100:991-1003.

O'Keeffe, A., J. Phelan, K. Keogh, and P. Kelly. 1982. Studies of milk composition and its relationship to some processing criteria: IV. Factors influencing the renneting properties of a seasonal milk supply. Irish J. Food Sci. Technol. 6:39-47.

Oldfield, D. J. 1996. Heat-induced whey protein reactions in milk: Kinetics of denaturation and aggregation as related to milk powder manufacture. PhD Thesis. Massey University, Palmerston North, New Zealand. .

Oldfield, D. J., H. Singh, and M. W. Taylor. 1998. Association of $\beta$-lactoglobulin and $\beta$-lactalbumin with the casein micelles in skim milk heated in an ultra-high temperature plant. Int. Dairy J. 8:765-770. https://doi.org/10.1016/S0958-6946(98)00127-7.

Ostersen, S., J. Foldager, and J. E. Hermansen. 1997. Effects of stage of lactation, milk protein genotype and body condition at calving on protein composition and renneting properties of bovine milk. J. Dairy Res. 64:207-219.

Palmy Weather. 2019. Historic trends and graphs. Accessed Mar. 19, 2019 http://palmyweather.co.nz/trendshistoric.

Park, Y. W. 1991. Relative buffering capacity of goat milk, cow milk, soy-based infant formulas, and commercial nonprescription antacid drugs. J. Dairy Sci. 74:3326-3333.

Phelan, J., A. O'Keeffe, M. Keogh, and P. Kelly. 1982. Studies of milk composition and its relationship to some processing criteria: 1. Seasonal changes in the composition of Irish milk. Irish J. Food Sci. Technol. 6:1-11.

Regester, G. O., and G. W. Smithers. 1991. Seasonal changes in the $\beta$-lactoglobulin, $\alpha$-lactalbumin, glycomacropeptide, and casein content of whey protein concentrate. J. Dairy Sci. 74:796-802.

Robitaille, G., K.-F. Ng-Kwai-Hang, and H. G. Monardes. 1991. Variation in the N-acetyl neuraminic acid content of bovine $\kappa$-casein. J. Dairy Res. 58:107-114.

Singh, H. 2004. Heat stability of milk. Int. J. Dairy Technol. 57:111119 .
Singh, H., and L. K. Creamer. 1991. Denaturation, aggregation and heat stability of milk protein during the manufacture of skim milk powder. J. Dairy Res. 58:269-283.

Singh, H., and P. F. Fox. 1985. Heat stability of milk: pH-dependent dissociation of micellar $\kappa$-casein on heating milk at ultra high temperatures. J. Dairy Res. 52:529-538.

Singh, H., and P. F. Fox. 1987. Heat stability of milk: influence of colloidal and soluble salts and protein modification on the $\mathrm{pH}$-dependent dissociation of micellar k-casein. J. Dairy Res. 54:523-534.

Singh, H., and J. M. Latham. 1993. Heat stability of milk: aggregation and dissociation of protein at ultra-high temperatures. Int. Dairy J. 3:225-237.

Singh, H., M. S. Roberts, P. A. Munro, and C. T. Teo. 1996. Acid-induced dissociation of casein micelles in milk: Effects of heat treatment. J. Dairy Sci. 79:1340-1346.

Tsioulpas, A., M. J. Lewis, and A. S. Grandison. 2007. Effect of minerals on casein micelle stability of cows' milk. J. Dairy Res. 74:167-173.

Van Slyke, D. D. 1922. On the measurement of buffer values and on the relationship of buffer value to the dissociation constant of the buffer and the concentration and reaction of the buffer solution. J. Biol. Chem. 52:525-570.

Vasbinder, A. J., and C. G. De Kruif. 2003. Casein-whey protein interactions in heated milk: the influence of pH. Int. Dairy J. 13:669677.

Walstra, P., and R. Jenness. 1984. Dairy Chemistry and Physics. John Wiley \& Sons, New York, NY.

Wijayanti, H. B., N. Bansal, and H. C. Deeth. 2014. Stability of whey proteins during thermal processing: A review. Compr. Rev. Food Sci. Food Saf. 13:1235-1251.

Wiking, L., J. Stagsted, L. Björck, and J. H. Nielsen. 2004. Milk fat globule size is affected by fat production in dairy cows. Int. Dairy J. 14:909-913.

Ye, A., H. Singh, M. W. Taylor, and S. Anema. 2002. Characterization of protein components of natural and heat-treated milk fat globule membranes. Int. Dairy J. 12:393-402. 